\author{
УДК 323.21 \\ https://doi.org/10.34142/24130060.2019.18.2.13
}

\title{
ПРОБЛЕМА НАЦІОНАЛЬНОГО СУВЕРЕНІТЕТУ В КОНТЕКСТІ СУЧАСНИХ МІЖНАРОДНИХ ВІДНОСИН
}

\author{
О.О. Поліщук
}

У статті розглядаються різні аспекти проблеми національного суверенітету в сучасних міжнародних відносинах. Пропонується визначення змісту «суверенітет» $у$ широкому історичному контексті, здійснюється стислий огляд розвитку змісту изього поняття, досліджуються причини і наслідки трансформації иього феномену в сучасних умовах.

Зазначається, щзо як і багато інших термінів соціально-гуманітарних дисциплін поняття «суверенітет» не має загального й однозначного визначення, а відмінності у його трактуванні зазвичай суперечать одна одній. Наголошується, щьо головна причина изього є те, шзо феномен «суверенітет» знаходився в процесі постійного розвитку, в межах якого держави створювали, втрачали і передавали іншим політичним акторам частину своїх державних функиій. Саме тому теоретичні уявлення про суверенітет $i$ практика їх реалізації суттєво відрізнялися. Обгрунтовується, щзо перспективним для сучасної політичної науки є визначення суверенітету держави, щуо передбачає існування двох основних аспектів: здатність держави самостійно представляти свою владу на території, яка окреслена державним кордоном або позначена іншими ознаками належності до даної території, яку держава контролює, та спроможність самостійно приймати рімення в міжнародних відносинах.

Ключові слова: держава, національний суверенітет, зовнішня політика, глобалізація, міжнародні відносини.

\section{ПРОБЛЕМА НАЦИОНАЛЬНОГО СУВЕРЕНИТЕТА В КОНТЕКСТЕ СОВРЕМЕННЫХ МЕЖДУНАРОДНЫХ ОТНОШЕНИЙ}

\section{О.А. Полищук}

В статье рассматриваются различные аспекты проблемы национального суверенитета в современных международных отношениях. Предлагается определение содержания «суверенитет» в иироком историческом контексте, осуществляется краткий обзор развития содержания этого понятия, исследуются причинь и последствия трансформации этого феномена в современных условиях.

Отмечается, что как и многие другие термины сочуиально-гуманитарных дисциплин, понятие «суверенитет» не имеет общего и однозначного определения, а различия в его трактовке часто противоречат друг другу. Отмечается, что главной причиной этого является то, что феномен «суверенитет» находился в процессе постоянного развития, в рамках которого государства создавали, теряли и передавали другим политическим актерам часть своих функций.

Именно поэтому теоретические представления о суверенитете и практика их реализачии существенно отличались. Обосновывается, что перспективным для современной политической науки является определение суверенитета государства, которое предполагает существование двух основных аспектов: способность государства

(C) О.О. Поліщук, 2019 
самостоятельно представлять свою власть на территории, очерченной государственной границей или обозначенной другим признаком принадлежности к данной территории, контролируемой государством, и способность самостоятельно принимать решения в системе международных отношений.

Ключевые слова: государство, национальный суверенитет, внешняя политика, глобализачия, международные отномения.

\section{THE PROBLEM OF NATIONAL SOVEREIGNTY IN THE CONTEXT OF CONTEMPORARY INTERNATIONAL RELATIONS}

\section{O. Polishchuk}

The article discusses various aspects of the problem of national sovereignty in modern international relations. The definition of the content of «sovereignty» in a wide historical context is proposed, a brief review of the development of the content of this concept is carried out, the causes and consequences of the transformation of this phenomenon in modern conditions are investigated.

It is noted that, like many other terms of social and humanitarian disciplines, the concept of «sovereignty» does not have a common and unambiguous definition, and differences in its interpretation are often contradictory. It is noted that the main reason for this is that the phenomenon of "sovereignty» was in the process of constant development, in which states created, lost and transferred to other political actors the part of their functions.

That is why the theoretical concepts of sovereignty and the practice of their implementation were significantly different. It is proved that the definition of state sovereignty is promising for modern political science, which implies the existence of two main aspects: the ability of the state to independently represent its power on the territory outlined by the state border or indicated by another sign of belonging to this territory controlled by the state, and the ability to make decisions independently system of international relations.

In other words, the concept of «sovereignty» can be understood as the ability of a state to perform certain actions without subordination to another state. Thus, in our time, the sovereignty of the state is its integral attribute and a sign of statehood. The main element of international relations was and is sovereign states with the division of powers into: legislative, executive and judicial, as well as control their own territory.

Key words: state, national sovereignty, foreign policy, globalization, international relations.

Постановка проблеми. Зростання актуальності проблеми національного суверенітету зумовлена масштабною демократичною уніфікацією у міжнародних відносинах, яка здійснюється євроатлантичними лідерами, а також глобалізаційними та регіонально-інтеграційними процесами.

Аналіз актуальних досліджень. Розгляд питання суверенітету здійснювали практично всі дослідники, які займалися вивченням правових норм формування держави та історією становлення і розвитку державної влади. Серед західних аналітиків слід відзначити: Р. Арона, С. Хангтінгтона, 
Ф. Фукуяму, С. Хоффмана. Також значний вклад у розробку цього питання зробили українські дослідники: В. Василенко, В. Бруз, Ю. Мацейко, В. Копійка, Т. Шинкаренко.

Мета статті - проаналізувати в широкому історичному контексті основні чинники трансформації теоретичних уявлень про суверенітет, а також його розуміння в сучасних міжнародних відносинах.

Виклад основного матеріалу. Як і багато інших термінів соціальногуманітарних дисциплін поняття «суверенітет» не має загального й однозначного визначення, а відмінності у його трактуванні зазвичай суперечать одна одній. Головною причиною цього $є$ те, що феномен «суверенітету» знаходився в процесі постійного розвитку, в межах якого держави створювали, втрачали і передавали іншим політичним акторам частину своїх державних функцій. Саме тому теоретичні уявлення про суверенітет і практика їх реалізації суттєво відрізнялися.

Перспективним для сучасної політичної науки $\epsilon$ визначення суверенітету держави, що передбачає існування двох основних аспектів: здатність держави самостійно представляти свою владу на території, яка окреслена державним кордоном або позначена іншими ознаками належності до даної території, яку держава контролює, та спроможність самостійно приймати рішення в міжнародних відносинах. Іншими словами, поняття «суверенітет» можна розуміти, як здатність держави чинити ті або інші дії без підпорядкування іншій державі. Відтак, в наш час суверенітет держави $є$ ii невід’ємним атрибутом і ознакою державності. Основним елементом міжнародних відносин були і є суверенні держави з розподілом влади на: законодавчу, виконавчу i судову, а також 3 контролем над власною територією.

Сьогодні проблема національного суверенітету стала головною у визначені подальшого розвитку Європи. Прихильники суверенітету вбачають у ньому європейські корені. Вони стверджують, що суверенітет став основою 
європоцентризму. Актуальність суверенітету особливо загострюється у періоди посилення внутрішніх і зовнішніх загроз.

Питання європейської єдності привертало увагу політиків під час протистояння держав, збільшення загрози знищення демократії. Під час Другої світової війни серед населення європейських країн зростала кількість прихильників ідеї пожертвування державним суверенітетом для отримання гарантій миру та безпеки. Після закінчення війни європейськими країнами для цього було обрано у якості найефективнішого об’єднання федеративний устрій. Суверенітет за умов існування федеративного устрою не можна поділити між федерацією та іï суб’єктами. Федерація - це одна держава, а не союз держав, які відмовляються від частини суверенітету на користь федеративної влади. У федеральній державі суверенітет належить федерації, а не її суб’ єктам. Цей принцип став основним для створення Свропейського Союзу, однак він суттєво обмежує суверенітет об'єднаних країн. В умовах міжнародної інтеграції ускладнилася координація чисельними бюрократичними структурами.

Звісно в історії міжнародних відносин абсолютного суверенітету не існувало ніколи. Держави при створені законів і укладанні договорів могли відмовитися від частини свого суверенітету. Підтвердженням цього можуть бути зобов’язання низки держав виконувати рішення Європейського Суду 3 прав людини за скаргами власних громадян, глобальне втручання ЗМІ в державні справи тощо.

Виділяють два засоби обмеження суверенітету: добровільний i примусовий. У першому випадку обмеження суверенітету відбувається тоді, коли кілька держав об'єднуються в союз, віддаючи частину прав на користь наднаціональних органів влади. Найбільших досягнень у застосуванні цього типу обмеження суверенітету здобули у країнах Євросоюзу. У Євросоюзі відмовилися від розмежування внутрішньої та зовнішньої політики. Відносини між його членами передбачають добровільний обмежений 
суверенітет i можливе втручання ззовні у випадку порушення домовленостей.

Примусове обмеження суверенітету відбувається тоді, коли одна держава втручається у справи іншої з метою врегулювання їі внутрішніх конфліктів. Таке втручання здійснюється без згоди держави і без міжнародних санкцій.

Першими концепцію суверенітету (в сучасному розумінні) обгрунтували державні діячі Західної Свропи в період пізнього середньовіччя (Т. Гоббс (1989), Ж. Боден (1962), А.-Ж. Ришельє (2008, с. 277)). Проте ця політико-філософська доктрина не була лише європейською розробкою. Насправді суверенітет виступає головними політичною i юридичною ознаками держави в усіх цивілізаціях. Зміст цього поняття відрізнявся в залежності від ідеологічного трактування за історичних обставин. Вже в перших письмових міжнародно-правових документах - наприклад, договорі єгипетського фараона Рамзеса II і хетського царя Хаттушиля III у 1296 р. до н.е. - обидва монархи ототожнювали державу і володаря, визнавали лінію кордону між своїми країнами і легітимність влади в країнах. Також вони співпрацювали в напрямку повернення перебіжчиків і їхнього майна в місця, які втікачі намагалися залишити, і в спільному протистоянні зовнішньому ворогу, а також в придушені заколотів (Зорина и др. ред., 1959, с. 344).

У різні історичні епохи зразки європейської доктрини суверенітету були представлені на основі «балансу сил» в регіональних міжнародних системах з кількома головними учасниками. Усвідомлюючи суверенітет як свободу, представники незалежних держав вважали його найвищою цінністю, а представники могутніх імперій всіляко заперечували його в теорії i на практиці. Цілком природним було те, що ця доктрина сформувалася в період створення в середньовіччі великих централізованих держав, яке стало відповіддю національних монархій (Англії та Франції) на гегемоневські напади Священної Римської імперії, фінансово-релігійні вимоги Римських пап і феодальний сепаратизм. 
Ствердження концепції суверенітету відбувалося не в наукових дискусіях, а в численних дипломатичних переговорах i війнах. Після останньої провальної спроби Габсбургів підпорядкувати собі німецьких князів ідея щодо загальної європейської імперії остаточно зазнала поразки. В результаті Вестфальський мир 1648 року затвердив право кожного монарха бути повноправним розпорядником у межах своїх територій і впроваджувати власну зовнішню політику, що остаточно визнало ідею суверенітету.

Прибічники ідеї абсолютизму 16-18 століть наділяли суверенітетом монарха, а ідеологи Просвітництва (Вольтер, Руссо) звинуватили сам політичний інститут монаршої влади в егоїзмі та байдужості до інтересів народу. Вони стверджували, що монархи переслідують лише свої власні інтереси, прагнуть збільшити свої території, встановити жорсткий деспотизм в середині країни, ігнорують потреби населення. Прихильники буржуазних ідей вважали недопустимим розглядати міжнародні відносини як взаємини між монархами. Ідеям божественної природи королівської влади вони протиставляли ідеї нації та національного суверенітету. Це передбачало право свободи вибору нації політичного режиму, соціального ладу, незалежного курсу зовнішньої політики. Таким чином, сувереном проголошується не монарх, а нація, яка є єдиним джерелом влади.

Конкретизуючи вищевикладене, слід відзначити, що інтересам вузьких буржуазних верств населення протиставлялися інтереси нації, що дозволило прибічникам ідей останньої здобути широку підтримку в боротьбі 3 абсолютизмом.

У результаті загального визнання в Свропі (після ухвалення Вестфальського миру 1648 р.) концепція суверенітету поступово поширилася в усьому світі. Відтак, у 20 столітті кодифікація міжнародного права, створення ООН та Ліги Націй затвердили суверенітет як основну засаду побудови міжнародних відносин. Однак, попри все практика світової політики не зазнала суттєвих змін. 
Суверенітет передбачає рівні права між державами, а також неможливість втручання у внутрішні справи інших, але цей факт у сучасному світі протиставляється рівню розвитку країни, кількості населення, обсягу природних ресурсів. Відтак, виникає своєрідна формальна ієрархія, яка передбачає те, що більш могутні країни мають «більш рівний» суверенітет. Підтвердженням цього може бути твердження Фукідіда, що «У людських взаєминах право має сенс лише у випадках, коли обидві держави визнають спільну необхідність. В іншому випадку, сильний отримує можливе, а слабкий змушений підкоритися» (Фукидид, 1999, с. 432).

Як багато століть тому, так і сьогодні, непорушність суверенітету виявляється абстрактною теорією, яка знаходить своє підтвердження лише при наявності силового потенціалу в державі. Для слабких країн розроблені концепції так званих «несуверенних» та «напівсуверенних» держав. В теорії міжнародного права i в практиці світової політики передбачені значні обмеження суверенітету слабких держав. На зміну колоніальним володінням минулого прийшли нові форми відносин залежності, які приховують обмеження державного суверенітету. Для втручання у справи нібито суверенних держав застосовують «гуманітарні інтервенції», «примушення до миру», «миротворчі операції».

Насамперед така практика стала поширеною через припинення свого існування біполярної міжнародної системи. Вже на початку 21 століття в світовій практиці був здійснений відхід від безумовного визнання державного суверенітету. Переконуючи міжнародну спільноту в необхідності забезпечення прав і свобод особистості в посттоталітарних державах, впливові світові політики неодноразово наголошували на відсутності потреби дотримання суверенітету i територіальної цілісності, бо «старі інститути» не дають досягти перемоги «гуманізму» і «демократії».

У результаті утвердження таких нових положень Генеральний секретар ООН К. Аннан на 54-й сесії Генеральної Асамблеї ООН чітко розмежував концепції державного та індивідуального суверенітетів. Аргументуючи тим, 
що в сучасних міжнародних відносинах в розумінні обох цих понять відбулися значні зміни, він наголосив на пріоритеті прав і свобод кожної окремої людини. Це означає, що індивідуальний суверенітет посилюється, а державний зазнає занепаду. Він відзначив, що традиційні принципи невтручання у внутрішні справи інших країн, державної незалежності втрачають свою силу і більше не здатні слугувати надійним захистом від репресивних диктаторських режимів, тож хоча подібна трансформація концепції державного суверенітету «буде сприйнята багатьма зі скептицизмом i, навіть ворожістю», але це «та еволюція, яку ми повинні вітати» (Аннан, 1999).

Після подій 11 вересня 2001 року США проголосили доктрину зміни політичних режимів в інших країнах і попереджувальних заходів як головний елемент своєї зовнішньополітичної стратегії. Так були розпочаті військові операції проти Іраку та Афганістану. Раніше США були засновником більшості світових універсальних організацій (OOH, Ліга Націй). Пізніше Вашингтон почав розривати усі угоди, які обмежували його простір для маневру. Свідченням цього може бути заява одного високо посадовця адміністрації Дж. Буша колишньому командувачу силами НАТО в Європі генералу У. Кларку після війни в Югославії: «Ніхто не в праві говорити нам, де ми можемо чи не можемо бомбити» (Weasley, 2002, с. 221).

Необхідно зазначити, що агресивна зовнішня політика США супроводжувалася масштабною ідеологічно-пропагандистською кампанією i в академічній сфері. Так у великій кількості статей неоконсервативні автори (Бхагвати (2005); Фридман (2007); Фукуяма (2004); Friedman (1999); Ohmae (1995); Ohmae (1995)), зокрема, Ф. Фукуяма та Т. Фридман виступаючи прихильниками процесів «демократизації» i «глобалізації», почали стверджувати, що ці процеси створюють якісно новий динамічний світ без обмежень і кордонів та об’єднують в єдине ціле міжнародну спільноту. Вони відзначають, що вже зараз глобалізація охопила всі сфери суспільного життя - економічну, політичну і культурну. Процес глобалізації змінив всі соціальні 
устрої, а суверенна держава перестала бути основним елементом світового порядку. Вони стверджують, що відбувається занепад суверенних країн, слабшають внутрішні суспільні структури. Це призводить до формування нового типу «громадян світу», які лояльні не до окремих держав, а до глобального громадянського суспільства. Надалі зростаюча політична i економічна взаємозалежність, науково-технічна революція та нові форми організації людства не залишать місця для суверенної держави-нації, перетворивши традиційний інститут територіально обмеженого правління на історичний анахронізм і політичну аномалію (Фукуяма, 2004, с.188).

Таким чином прихильники глобалізації вважають природнім занепад держави-нації і бажаним результатом суспільного прогресу. Вони відзначають, що самі суверенні держави є головною причиною війн i економічних криз. Вирішити ці проблеми можливо лише трансформувавши світову політичну систему в єдину універсальну державу. Це передбачає відмову всіх країн від суверенітету на користь всесвітньої імперії з урядом, який буде вповноважений видавати постанови обов’язкові для всіх народів.

3 подібними прогнозами переходу суверенних держав до глобальних світових структур цікаво співвідносяться різноманітні передбачення розростання існуючих держав Свропейського Союзу і прогресуючі тенденції регіоналізації європейської політики. На початку 21 століття підрозділ прогнозованих досліджень при Сврокомісії оприлюднив своє бачення розвитку основних напрямків ЄС упродовж наступних десяти років. Усі сценарії передбачали суттєве зростання ролі регіонів, а в деяких варіантах вони отримували функції національних держав. Однак, прогнозуючи поступове загострення кризи, залишилося не визначеним питання відносно того, чому неефективним виявився саме державний рівень адміністрування, чому воно не зачепило загальноєвропейський та місцевий рівні.

Інші аналітики зазначають, що світова політика суттєво не змінила свого характеру, залишившись полем боротьби за владу i матеріальні ресурси. Відкинувши усі плюси і мінуси процесів глобалізації, необхідно 
відзначити, що бажане ще не означає дійсне. Глобальне громадянське суспільство орієнтоване не на могутність держави, а на людські права. Незважаючи на бажання i фантазії про «кінець історії» i «неминучу глобалізацію», основними політичними гравцями на світовій політичній арені $\epsilon$ і будуть найближчим часом егоїстично налаштовані держави-нації чи держави-імперії. Держави нині визначають структуру світової політики та встановлюють міжнародні режими. Вони ж контролюють матеріальні та інтелектуальні ресурси і впливають на недержавних акторів.

Протягом останнього століття держава значно розширила свої функції. Однак неоднорідність світового співтовариства призводить до асиметрії серед існуючих держав-націй. Незначна кількість держав $\epsilon$ могутніми центрами, а решта мають лише формальні атрибути: гімн, прапор, герб. Наймогутніші держави намагаються бути лідерами певного регіону, мобілізують своє оточення у своїх інтересах, і впливають на внутрішню та зовнішню політику сусідів. Найбільший такий вплив здійснюють «великі держави». Ці держави ніколи не тяжіли до підпорядкування юридичним нормам, а скоріше намагалися встановлювати ці норми.

Можна констатувати той факт, що глобалізація не знищила державний суверенітет, «ринок» у повній мірі залежить від правил регулювання національних урядів. США завдяки своїй могутності і економічним ресурсам дійсно відкрили світову економіку. Однак правила поведінки тут встановлюють не принципи «вільної торгівлі», а конкретні національні інтереси. Відчуваючи конкуренцію 3 боку «малих держав», лідируючі держави встановлюють певні обмеження. Таким чином вони захищають власний ринок, незважаючи на проголошення вільної торгівлі. Прикладом може бути коментар 3. Бжезінського до положення Т. Фрідмана про вирівнювання можливостей: «Рівний» ігровий майданчик перекошується кожного разу, коли це зачіпає інтереси США» (Бжезинский, 2004, с. 241). Тобто, творцями глобалізації $є$ «великі держави», які у разі необхідності можуть самоусунутися від глобальних обов'язків. 
Висновки та перспективи подальших досліджень. Слід відзначити, що у сучасному світі відбулася певна еволюція змісту феномена суверенітету, однак такі складові як: політична, економічна, культурна не зазнали істотних змін. Зміна розуміння суверенітету в умовах глобалізації дуже складна. Так сфера національного суверенітету одночасно розширюється і звужується, змінюючи реалізацію державою своїх функцій. В економічній сфері зміна суверенітету проявляється в частковому переході державних функцій до недержавних акторів, які ефективніше підготовлені для їх виконання. Для кращого функціонування національної економіки державний і приватний сектори стали застосовуватися комплексно.

Стосовно краху державного суверенітету необхідно відзначити, що в даному випадку доречніше говорити про занепад певних країн. Наймогутніші світові держави використовують можливості глобалізації для захисту своїх власних інтересів, а слабкі країни через тиск могутніх вимушені підлаштовуватися під встановлені правила. Це у певній мірі нагадує кастову систему, в якій приналежність до однієї касти не дозволяє змінити свій статус. Таким чином зв’язок слабкості і залежності не дозволяє подолати сили і впливовості. Ми можемо спостерігати цю тенденцію і констатувати ¥і1 збереження.

\section{ЛІТЕРАТУРА}

1. Аннан, К., 1999. Две концепции суверенитета: выступление на 54-й сессии Генеральной Ассамблеи ООН в Нью-Йорке. Независимая газета. 20 сент.

2. Бхагвати, Д. В. 2005. В защиту глобализащии. Москва: Ладомир.

3. Бжезинский, 3. 2004. Выбор. Глобальное господство или глобальное лидерство. Москва: Международные отношения.

4. Гоббс, Т., 1989. Сочинения: в 2-x m. Перевод с латинского и английского В.В. Соколов. Москва: Мысль.

5. Зорина, В. А., Семенова, В. С., Сказина, С. Д. и Хвостова В. М. ред., 1959. История дипломатии. 2-е изд. Т.1. Москва: Государственное издательство политической литературы.

6. Ришелье, А.-Ж., 2008. Политическое завещзание, или принципь управления государством. Перевод с французского Л.А. Сифуровой. Москва: Ладомир.

7. ридман, Т. 2007. Плоский мир: краткая история 21 века. Москва: АСТ; Хранитель. 
8. Фукидид, 1999. История. Перевод с латинского Г.А. Стратановського. Москва: Ладомир; ООО «Фирма «Издательство АСТ»».

9. Фукуяма, Ф., 2004. Конец истории и последний человек. Перевод с английского М.Б. Левина. Москва: ООО «Издательство АСТ: ЗАО НПП «Ермак».

10. Bodin, J. 1962. The Six Books of Commonwealth. Cambridge: Cambridge University Press.

11. Friedman, Th. 1999. Understanding Globalisation. The Lexus and the Olive Tree. N.Y.: Farrar, Straus and Giroux.

12. Ohmae, K. 1990. The Borderless Word. London: Colins.

13. Ohmae, K. 1995. The End of the Nation State. N.Y.: Free Press.

14. Weasley, K., 2002. Clark Waging Modern War: Bosnia, Kosovo, and the Future of the Combat. N.-Y.: Public Affairs.

\section{Інформація про авторів}

Поліщук Олег Олександрович - незалежний дослідник (м. Харків); e-mail: olegpolishuk@ukr.net; ORCID: http://orcid.org/0000-0001-5438-7763.

Стаття надійшла до редакції: 20.02.2019 р. $\quad$ Прийнята до друку: 06.03.2019 p. 